\title{
Raw Material Sources and the Possibility of Studying Hunter-Gatherer Mobility as Seen on Selected Late Upper Palaeolithic and Mesolithic Sites in Bohemia
}

\author{
Petr Š́da ${ }^{a}$, Dagmar Vokounová Franzeováa, Marta Moravcováa \\ ${ }^{a}$ Department of Archaeology, Faculty of Arts, University of West Bohemia in Plzeň, Sedláčkova 15, Plzen̆ 30614, Czech Republic
}

\section{ARTICLE INFO}

\section{Article history:}

Received: 15 May 2012

Accepted: 28 August 2012

\section{Keywords:}

hunter-gatherers

Late Palaeolithic

Mesolithic

Mobility

stone raw material

\begin{abstract}
A BSTRACT
This article presents a study of the mobility of Late Palaeolithic and Mesolithic hunter-gatherer groups which settled in the area of the upper Otava, the Bohemian Paradise and the Central Bohemia region. The exploitation models are derived on the basis of a determination of the stone raw material composition of selected lithic industry assemblages together with a derivation of the transport distance of the individual rocks and minerals. The exploitation models are, in other words, structures in stone raw material reflecting the action radius of the human communities and providing a tool for understanding the spatial behaviour and its changes over time.
\end{abstract}

\section{Introduction}

The study of regional binding of Palaeolithic and Mesolithic sites has a long tradition in this country ( $c f$. Svoboda, ed. 2003; Vencl et al. 2006; Škrdla 2005). These studies deal with a list of sites on a specific area and from the nature of the employed data provide a statistical picture of the situation. We are therefore not able to distinguish the timeline of events, or their spatial relationships. We need more additional information in order to obtain a dynamic picture of the relationships between the sites. The first category of information consists of detailed chronological data. In principle, these data can only be obtained by detailed studying of the stratified sequences which allows for detailed dividing and precise dating of the entire layers. This study does not allow for open-air sites created by overlapping of numerous settlement events.

A further category of information is represented by spatial relationships. The original dynamic network of settlements consisted of several cores (communities), which, based on

\footnotetext{
*Corresponding author. E-mail: petrsida@seznam.cz
}

their needs, moved around a certain area. The result of this dynamic process is a static image of the current large number of sites, of which only a small part was actually present at the same time. To understand the dynamic image of the researched area we need to know one basic parameter, this being the size of the utilized space. It affects the density of the communities in the surveyed area and thus the number of existing sites at one moment.

Chronological and spatial relationships can be studied indirectly through the use of artefact puzzles, although they are significantly affected by the fragmentation of data entering the analysis. In order to understand the dynamic relationships in the area we need twofold: to bring the time into the scheme of sites (within the meaning of a detailed chronology over the course of centuries, the dating within the framework of the millennia, which we are able to determine on the basis of artefacts, is insufficient).

The chronological methods based on absolute dating will never be accurate enough to be able to capture the contemporaneity, or subsequence of the individual sites (in addition, we have to be aware of the fact that we archaeologically explore only a limited selection of the revealed sites). Therefore, we must try to understand the 
spatial behaviour and its changes over time. The resulting image will not be a dynamic picture of past events, but respectively a reflection of archaeological sources. The determination of time is too coarse for this, and the available data is too fragmentary. We may be able, however, to find general patterns of behaviour, a kind of quasi-dynamic model of previous events.

In this paper we focus on only one aspect of this model, which will be the determination of the size of the settlement areas and its changes from the Late Palaeolithic into the Mesolithic. Monitoring the types of used raw materials can be extremely effective in revealing the utilized space. The initial results have already indicated that such a procedure is not only possible but also beneficial (Š́da et al. 2011). We would therefore like to test a larger sample of data.

\section{Methodology}

For this study, we collected a set of data consisting of determined chipped stone industry collections. The only aspect which will be discussed is the macroscopic determination of the stone raw material of the artefacts. The collection was selected in order to ensure that the dating was as accurate as possible and also by the number of determined artefacts (the number was set at a minimum of 30 pieces).
To avoid the divergence caused by an inability to verify the initial determination, we selected only those sites where we determined all the materials on our own.

We proceeded in the transect leading from the southern border of Bohemia at the Šumava (upper Otava) over Central Bohemia to the north to the Bohemian Paradise (Český ráj). In the collections we monitored the representation of individual types of raw material and their transport distance. From this determination we derived the graphs of the relationship between the employed raw materials and the transport distance. These graphs determined the size of the exploited area. We monitored the distance at which the quantities of the raw materials increased at 25, 50, 75 and $90 \%$ of the collection (Figures 1 and 2).

\section{Sites}

\subsection{Babí pec (Loktuše village, Semily district)}

This archaeological site lies at the foot of Kozákov Hill, in a Cenomanian sandstone block and represents one of the biggest abri (opened to the south) in the Bohemian Paradise. The archaeological research at Babí pec was conducted by V. Vaníček and J. V. Šimák in 1936 and provided a large number of lithic industries. The assemblage housed in the Museum of the Bohemian Paradise in Turnov is from
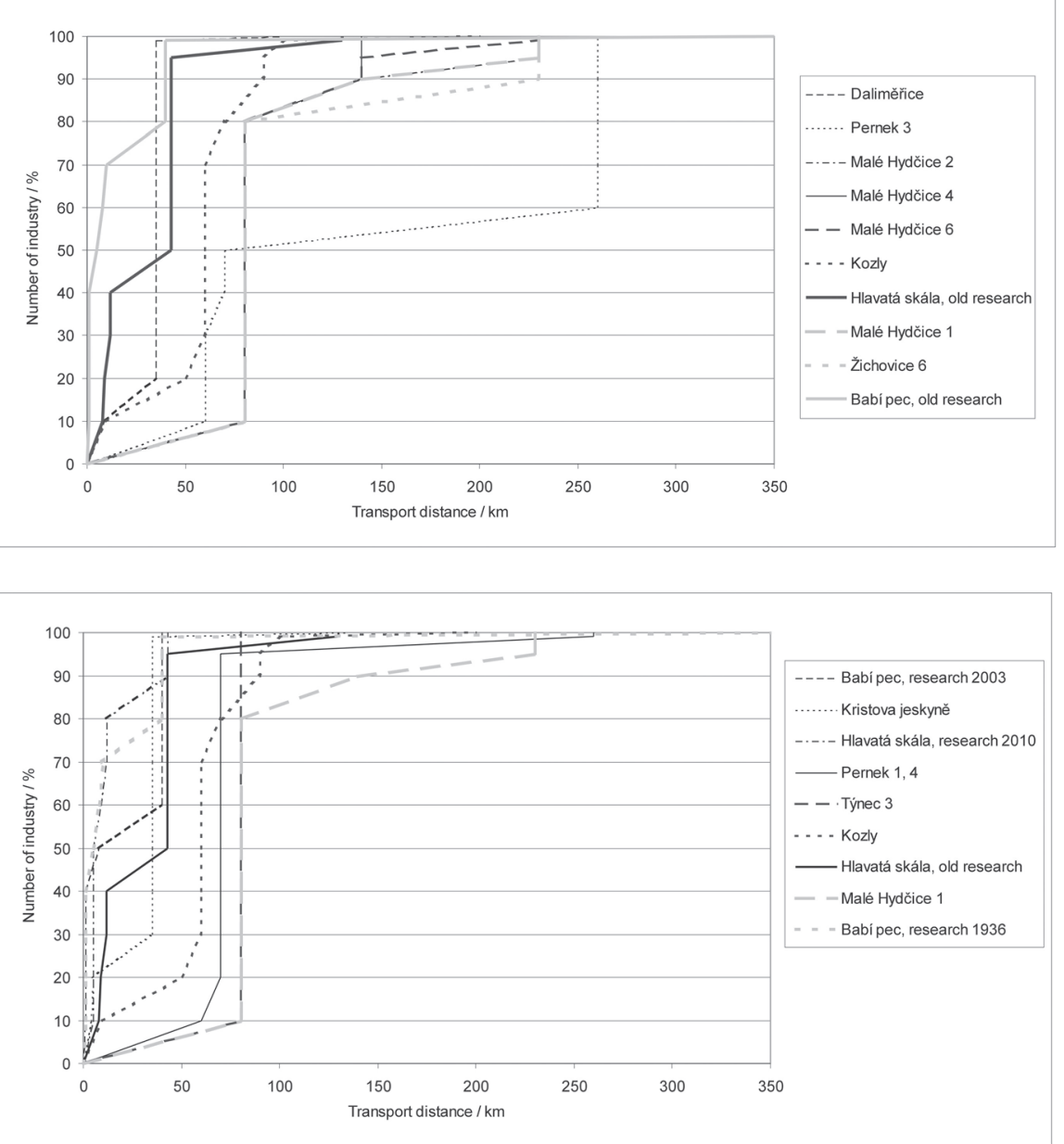

Figure 1. Late Palaeolithic and Late Palaeolithic-Mesolithic sites. Graphic display of the relationship between the quantity of raw material and the transport distance.

Figure 2. Mesolithic and Late PalaeolithicMesolithic sites. Graphic display of the relationship between the quantity of the raw material and the transport distance. 
Table 1. Babí pec. Origin of the stone raw materials, assemblage obtained in 1936 (Mesolithic, Late Palaeolithic admixture).

\begin{tabular}{lcccc}
\hline \multicolumn{1}{c}{ Stone raw material } & Distance & \% & \% Cumulative & \% Cumulative modified \\
\hline local sources from Kozákov Hill & 1 & 49.4 & 49.4 & 49.8 \\
rocks from fluvial sediments of the Jizera River & 5 & 6.7 & 56.1 & 56.6 \\
Permian sediments of the Krkonoše Mountain foothill basin & 8 & 12.5 & 68.6 & 69.2 \\
local sources apart from Kozákov Hill & 10 & 4.3 & 72.9 & 73.5 \\
area of continental glaciations (drift flints) & 40 & 25.6 & 98.5 & 99.3 \\
Bečov type quartzite & 110 & 0.1 & 98.6 & 99.4 \\
Tušimice type quartzite & 140 & 0.1 & 98.7 & 99.5 \\
Bavarian banded chert & 350 & 0.5 & 99.2 & 100 \\
non determined & $?$ & 0.8 & & \\
\hline
\end{tabular}

Table 2. Babí pec. Origin of the stone raw materials, assemblage obtained in 2003 and 2006 (Mesolithic).

\begin{tabular}{|c|c|c|c|c|}
\hline Stone raw material & Distance & $\%$ & $\%$ Cumulative & $\%$ Cumulative modified \\
\hline local sources from Kozákov Hill & 1 & 40.7 & 40.7 & 41.1 \\
\hline rocks from fluvial sediments of the Jizera River & 5 & 3.9 & 44.6 & 45.0 \\
\hline Permian sediments of the Krkonoše Mountain foothill basin & 8 & 9.6 & 54.2 & 54.7 \\
\hline local sources apart from Kozákov Hill & 10 & 3 & 57.2 & 57.7 \\
\hline area of continental glaciations (drift flints) & 40 & 41.9 & 99.1 & 100 \\
\hline non determined & $?$ & 0.6 & & \\
\hline
\end{tabular}

this period. The studied part of the assemblage involved 1014 artefacts. Revision research at the site, where the 332 artefacts analysed for the purpose of this article come from, was conducted by P. Šída and J. Prostředník in 2003 and 2006. Most of the industry belongs to the Mesolithic, although the presence of Late Palaeolithic artefacts in the assemblage from 1936 should not be excluded as a possibility (Šída 2007; Šída, Prostředník 2007; Prostředník, Š́da 2010).

The stone raw material composition of the assemblage obtained in 1936 is shown in Table 1. Most of the industry was chipped from local materials at Kozákov Hill (49.4\%), which comes from a maximum distance of $1 \mathrm{~km}$ (jasper, cornelian, agate and also melafyr). The stone raw materials collected by previous humans from fluvial sediments of the Jizera River are available approximately up to $5 \mathrm{~km}$ and make up $6.7 \%$ of the production materials (quartz, crystal rock, metabasic of the Jizerské hory type, gneiss and phyllite). Rocks from the Krkonoše Mountain foothill basin (12.5\% of the production materials; opaljasper in other words, limnetic silicite of Permian-Carboniferous sediments) were transported from a distance of approximately $8 \mathrm{~km}$. Additional local sources include outcrops available up to $10 \mathrm{~km}$ from the sites $(4.3 \%$ of the production materials; sandstone, basalt, quartzite, cretaceous porcellanite). Drift flints represent a stone raw material with sources located at a distance of approximately $40 \mathrm{~km}$ and make up $25.6 \%$ of the collection. Only a particularly small part of the production materials come from a distance exceeding $100 \mathrm{~km}$. The Bečov type quartzite was transported from $110 \mathrm{~km}$ distant outcrops $(0.1 \%$ of the collection), the Tušimice type quartzite comes from a distance of $140 \mathrm{~km}$ ( $0.1 \%$ of collection) and the outcrops of Bavarian banded cherts are located about $350 \mathrm{~km}$ from the site at Babí pec $(0.5 \%$ of the production materials). The remaining stone raw materials $(0.8 \%)$ could not be determined.
The stone raw material composition of the chipped industry, which was founded during the revision researches in 2003 and 2006 is provided in the attached table (Table 2). This assemblage is also characterised by a high frequency of Kozákov Hill minerals (40.7\%; transport distance of up to $1 \mathrm{~km}$ ). There was occasional chipped material from fluvial sediments of the Jizera River (3.9\%), stones from the Krkonoše Mountains foothill basin make up 9.6\% of the assemblage by the stone artefacts producers. Additional local rocks and minerals from the outcrops lying up to $10 \mathrm{~km}$ from the sites made up of $3 \%$ of the studied chipped industry. Drift flints of glacial and glaciofluvial sediments make up $41.9 \%$ of the production material (the distance to an area of continental glaciation in North Bohemia is approximately $40 \mathrm{~km})$. The remainder of the stone raw materials $(0.6 \%)$ could not be determined.

\subsection{Kristova jeskyně (Bělá u Turnova village, Semily district)}

Kristova jeskyně is a medium-sized abri located in a rock block at the Klokočské rocks near Rotštejn Castle. In 2001 the site was disturbed by illegal excavation conducted by a detector finder. Rescue archaeological research revealed Mesolithic layers with five fireplaces and 537 pieces of chipped industry in 2005 (Šída, Prostředník 2007; Prostředník, Šída 2010).

The stone raw material composition is shown in Table 3. $22.9 \%$ of the production materials come from the immediate surroundings of the archaeological site. The Jizera River as a source of chipped fluvial boulders ( $2.4 \%$ of collection; slate, sedimentary slate, quartz, metabasic of the Jizerské hory type) lies $2 \mathrm{~km}$ from the Kristova jeskyně site. The raw material of $14 \%$ of the stone industry (chalcedony, jasper, cornelian) was brought from the $4 \mathrm{~km}$ distant Kozákov Hill. Additional local rocks are present at a frequency of $6.5 \%$ (the maximum transport distance is $5 \mathrm{~km}$; porcellanite, silicified sandstone). 
Table 3. Kristova jeskyně. Origin of the stone raw materials, rescue research in 2005 (Mesolithic).

\begin{tabular}{lcccc}
\hline \multicolumn{1}{c}{ Stone raw material } & Distance & \% & \% Cumulative & \% Cumulative modified \\
\hline rocks from the fluvial sediments of the Jizera River & 2 & 2.4 & 2.4 & 2.4 \\
local sources from Kozákov Hill & 4 & 14 & 16.4 & 16.5 \\
local sources apart from the Kozákov Hill & 5 & 6.5 & 22.9 & 23.1 \\
Permian sediments of the Krkonoše Mountain foothill basin & 11 & 4.3 & 27.2 & 27.4 \\
area of continental glaciations (drift flints) & 35 & 71.7 & 98.9 & 99.6 \\
Tušimice type Quartzite & 134 & 0.4 & 99.3 & 100 \\
non determined & $?$ & 0.7 & & \\
\hline
\end{tabular}

Opaljasper and silicified slate of Permian sediments were available up to $11 \mathrm{~km}$ and amounted to $4.3 \%$ of the production material. The majority of the stone raw materials came from a distance of circa $40 \mathrm{~km}(71.7 \%)$. This group consisted of drift flints from glacial and glaciofluvial sediments of North Bohemia. Long-distance imports (transport distance over $100 \mathrm{~km}$ ) were only represented marginally by the Tušimice type quartzite $0.4 \%$ of the collection (transport distance $134 \mathrm{~km})$. The remainder of the stone raw materials $(0.7 \%)$ could not be determined.

\subsection{Hlavatá skála (Hrubá Skála village, Semily district)}

The first finds on site were uncovered at the beginning of the $20^{\text {th }}$ century. The lithic industry is apparently Mesolithic, with a portion associated with the Late Palaeolithic and which includes 185 artefacts. In 1996 the site was excavated by V. Vokolek. In Trench 1, made in the southern part of the site, he identified a thick cluster of three layers with hearths, but found only two artefacts. In 2005, we used charcoal from the second (middle) layer of these fireplaces to obtain the very first Mesolithic date for a site in Český ráj (Prostředník, Šída 2006). In autumn 2010 we reopened this trench, sieved the fill, and found several dozen Mesolithic artefacts (Š́ída, Prostř̌edník 2006; Filip 1947; Vokolek 1998; Prostředník, Šída 2006; Šída, Prostř́edník 2007; Šída, Prostřredník 2010).
Table 4 summarises the stone raw materials which were determined in an assemblage of chipped industry obtained at the beginning of the $20^{\text {th }}$ century. $22.4 \%$ of the used rocks come from the immediate surroundings of the site. Outcrops of jasper and cornelian at Kozákov Hill lie at a distance of $8 \mathrm{~km}$ and cover $15.7 \%$ of the previous human stone needs. From the $9 \mathrm{~km}$ distant riverbed of Jizera comes $3.2 \%$ of the production materials, with this involving quartz and metabasic of the Jizerské hory type. Porcellanites and basalt (3.2\% of the collection) rank among the local sources available up to $5 \mathrm{~km}$. Opaljasper of Permian sediments was available at a distance of $12 \mathrm{~km}$ and covered $17.8 \%$ of the production material. The transport distance of drift flints, which were chipped at a frequency of $56.8 \%$, was $43 \mathrm{~km}$. Long-distance imports make up only a marginal part of the stone raw material composition and include the Skršín type quartzite $(0.5 \% ; 105 \mathrm{~km})$ and the Tušimice type quartzite $(1.6 \% ; 130 \mathrm{~km})$. The remainder of the stone raw materials $(1.2 \%)$ was not determined.

An assemblage obtained during revision research in 2010 is dated to the Mesolithic period and involves 79 artefacts (Table 5). A major part of the industry (54.4\%) was chipped from local materials including basalts and porcellanites. From the $8 \mathrm{~km}$ distant Kozákov Hill, hunter-gatherers brought minerals (jasper, agate), which represent $2.6 \%$ of the lithic

Table 4. Hlavatá skála. Origin of the stone raw materials, assemblage obtained at the beginning of the $20^{\text {th }}$ century (Late Palaeolithic, Mesolithic).

\begin{tabular}{|c|c|c|c|c|}
\hline Stone raw material & Distance & $\%$ & $\%$ Cumulative & \% Cumulative modified \\
\hline local sources apart from Kozákov Hill & 5 & 3.2 & 3.2 & 3.2 \\
\hline local sources from Kozákov Hill & 8 & 15.7 & 18.9 & 19.1 \\
\hline rocks from the fluvial sediments of the Jizera River & 9 & 3.2 & 22.1 & 22.4 \\
\hline Permian sediments of the Krkonoše Mountain foothill basin & 12 & 17.8 & 39.9 & 40.4 \\
\hline area of continental glaciations (drift flints) & 43 & 56.8 & 96.7 & 97.9 \\
\hline Skršín type quartzite & 105 & 0.5 & 97.2 & 98.4 \\
\hline Tušimice type quartzite & 130 & 1.6 & 98.8 & 100 \\
\hline Non determined & & 1.2 & & \\
\hline
\end{tabular}

Table 5. Hlavatá skála. Origin of the stone raw materials, assemblage obtained during a revision research in 2010 (Mesolithic).

\begin{tabular}{lccc}
\hline \multicolumn{1}{c}{ Stone raw material } & Distance & \% & \% Cumulative \\
\hline local sources apart from Kozákov Hill & 5 & 54.4 & 54.4 \\
local sources from Kozákov Hill & 8 & 2.6 & 57 \\
rocks from the fluvial sediments of the Jizera River & 9 & 7.6 & 64.6 \\
Permian sediments of the Krkonoše Mountain foothill basin & 12 & 17.7 & 82.3 \\
area of continental glaciations (drift flints) & 43 & 17.7 & 100 \\
\hline
\end{tabular}


industry. Quartz collected by previous humans from fluvial sediments of the Jizera River was available at a distance of $9 \mathrm{~km}$ and makes up $7.6 \%$ of the production material. From the Permian sediments at a distance of $12 \mathrm{~km}$ from the site at Hlavatá skála come opaljasper, which was chipped at a frequency of $17.7 \%$. The same part of the stone artefacts (17.7\%) was made by Mesolithic hunter-gatherers from drift flints, which occur in North Bohemia $43 \mathrm{~km}$ away.

\subsection{Daliměřice (Daliměřice village, Semily district)}

This site on a significant promontory under the confluence of the Vazovecký stream and the Jizera River was the site of a small castle in the Middle Ages. Over the course of archaeological research led by J. Klápště (1980s), P. Břicháček collected 106 pieces of lithic industry belonging to the Late Palaeolithic cultural group Federmesser (Šída 2004).

Table 6 shows the presence of stone raw materials, their transport distance and the frequency of use. The list of materials from the shorter transport distance is as follows: quartz from fluvial sediments of the Jizera river $(1 \mathrm{~km}$; 8.5\%), jasper from Kozákov Hill (9 km; 5.7\%), opaljasper from Permian sediments $(20 \mathrm{~km} ; 1.9 \%)$, drift flints from an area of continental glaciation $(35 \mathrm{~km} ; 83 \%)$, quartzite of the Skršín type (100 km; 0.9\%).

\subsection{Kozly (Kozly village, Mělník district)}

The site in Kozly is located north-east of Prague in the Mělník district, between the villages of Kozly and Mlékojedy, at an altitude of 165 meters. The area of this surface site is formed by a south facing sand dune, which lies at the right bank of the old Elbe, approximately $125 \mathrm{~m}$ from the stream at a relative elevation of $3 \mathrm{~m}$. The dune is currently covered by cottages and forest (Petrbok 1937, 28; Sklenár 1982, 145; Sklenář 2000, 73).

The first artefacts from this site were collected by the amateur archaeologist Rudolf Šanovec in all probability between the years 1910 and 1912. The site at Kozly is primarily connected, however, with Jaroslav Petrbok, who discovered a microlithic industry here in 1915. Repeated surface collection conducted over the next several years provided one of the largest Mesolithic assemblages in Bohemia (Petrbok 1937, 28; Sklenář 2008, 47).

The studied assemblage consists of 1231 pieces of lithic industry housed in the National Museum in Prague. The results of the stone raw material analyses are shown in the attached table (Table 7). The majority of the industry is dated to the Mesolithic, while certain artefacts have Late Palaeolithic features. The spatial distribution of the outcrops of predominant stone raw materials face the north and north-west, towards the foothills of the Krušné Mountains, the foothills of the Krkonoše Mountains and the spurs and basins of North Bohemia. The majority of the determined rocks consist of drift flints $(33.5 \%)$ having originated from these spurs and basins, which are located circa $50 \mathrm{~km}$ from Kozly. The average transport distance of jasper, agate and chalcedony from Kozákov Hill is $60 \mathrm{~km}$, the percentage of use of these minerals is $3.9 \%$. This is the same source area and transport distance as is the case with opaljasper and cretaceous porcellanite. The metabasic of the Jizerské hory type $(0.9 \%)$ was brought from the natural outcrops at the foothills of the Jizerské Mountains, which are located $70 \mathrm{~km}$ away. The determined quartzites of north-west Bohemia (the area between the towns of Kadaň and Most) include the several times mentioned Bečov, Skršín and Tušimice types

Table 6. Daliměrice. Origin of the stone raw materials, assemblage obtained during research work over $1985-1987$ (Late Palaeolithic).

\begin{tabular}{lccc}
\hline \multicolumn{1}{c}{ Stone raw material } & Distance & \% & \% Cumulative \\
\hline local sources apart from Kozákov Hill & 1 & 8.5 & 8.5 \\
local sources from Kozákov Hill & 9 & 5.7 & 14.2 \\
Permian sediments of the Krkonoše Mountain foothill basin & 20 & 1.9 & 16.1 \\
area of continental glaciations (drift flints) & 35 & 83 & 99.1 \\
Skršín type quartzite & 100 & 0.9 & 100 \\
\hline
\end{tabular}

Table 7. Kozly. Origin of the stone raw materials, assemblage obtained by J. Petrbok (Mesolithic, Late Palaeolithic admixture).

\begin{tabular}{|c|c|c|c|c|}
\hline Stone raw material & Distance & $\%$ & $\%$ Cumulative & $\%$ Cumulative modified \\
\hline local rocks of Barrandian & 10 & 13.4 & 13.4 & 15.2 \\
\hline $\begin{array}{l}\text { Permian sediments of the Krkonoše Mountain foothill basin } \\
\text { including Kozákov Hill }\end{array}$ & 50 & 4.6 & 18 & 20.4 \\
\hline area of continental glaciations (drift flints) & 60 & 33.5 & 51.5 & 58.3 \\
\hline sources of the Czech Cretaceous Basin & 60 & 0.4 & 51.9 & 58.7 \\
\hline Bečov, Skršín and Kamenná Voda type quartzites & 60 & 25 & 76.9 & 87 \\
\hline metabasic of the Jizerské hory type & 70 & 0.9 & 77.8 & 88 \\
\hline Tušimice type quartzite & 90 & 8.4 & 86.2 & 97.5 \\
\hline sources from south Bohemia & 100 & 1.3 & 87.5 & 99 \\
\hline Krumlovský les type chert & 190 & 0.6 & 88.1 & 99.7 \\
\hline Bavarian Jurassic chert & 200 & 0.3 & 88.4 & 100 \\
\hline non determined & $?$ & 11.7 & & \\
\hline
\end{tabular}


as well as quartzite from the surroundings of the village of Kamenná Voda. The outcrops are located at a distance of 60 respectively $90 \mathrm{~km}$ and have the following features in the studied assemblage: the Bečov type (14.4\%), the Skršín type $(10.5 \%)$, the Tušimice type $(8.4 \%)$, the Kamenná Voda type $(0.1 \%)$. During the transport of stone raw materials from South Bohemia (opal, crystal rock, quartz, quartzite of the Lipnice type; $1.3 \%$ of assemblage) a distance of approximately $100 \mathrm{~km}$ had to be overcome. Outcrops of Moravian chert of the Krumlovský les type (190 km; 0.6\%) and of Jurassic Bavarian cherts (over $200 \mathrm{~km}$; 0.3\%) are situated even further. The remaining part of the raw material composition of the Kozly assemblage (13.4\%) consists of local materials available up to $10 \mathrm{~km}$ from the site. This category includes quartz and Proterozoic and Palaeozoic rocks of the Barrandian (phanite, quartzite, or spilite).

\subsection{Pernek 1, 3 and 4 (Pernek village, Český Krumlov district)}

The site at Pernek 3 was discovered by J. Fröhlich, O. Chvojka and the Šálek family during micro-probing in 2003. A detection probing followed on the no name hill, which significantly rises above Lipno dam (altitude $770 \mathrm{~m}$ ) in September 2006. This faraway visible and noticeable location is situated on the cadastre of the village of Pernek. The distance between the hill peak and the former Vltava river bank is circa $400 \mathrm{~m}$, while the elevation above the current Vltava reaches $45 \mathrm{~m}$ (the elevation above the former Vltava could have been circa $50 \mathrm{~m}$ ). The discovered lithic industry dates back to the Late Palaeolithic.

As early as 2000, prior to the appearance of the Pernek 3 site, surface collections at the south and west foothill of this no name hill were repeatedly carried out by J. Šálek and his family. In this manner every year stone chipped artefacts and prehistoric ceramic fragments were collected on the exposed east bank of Lipno dam, at a distance of circa 100-300 m from a railway bridge. The findings were consequently passed on for professional processing. In 2003, J. Fröhlich, O. Chvojka and the Śálek family also participated in the surface collections. This site was named Pernek 1 by S. Vencl (Vencl et al. 2006, 197-198; Šída, Fröhlich, Chvojka 2008).

At a distance of $200-300 \mathrm{~m}$ south-east of the site at Pernek 1, J. Figura found another assemblage of chipped industry in 2003, which was extended by J. Śálek - site Pernek 4 (Vencl et al. 2006, 198-199; Š́da, Fröhlich, Chvojka 2008). The consequent surface collection also provided stone artefacts from the space between these three sites. In the article the Mesolithic findings from Pernek 1 and 4 were analysed together.

The assemblage of chipped industry from Pernek 1 and 4 consists of 230 artefacts (Table 8). The local rocks (quartz) and minerals (crystal rock) represent $1.3 \%$ of the industry (transport distance up to $10 \mathrm{~km}$ ), $60 \mathrm{~km}$ distant sources of South Bohemia were exploited by a frequency of $10.4 \%$. Bavarian stropped cherts were transported over a distance of $70 \mathrm{~km}$ and made up more than $3 / 4$ of the production material (75.7\%). The silicified woods $(120 \mathrm{~km} ; 0.9 \%)$ in all probability originate from the Pilsen basin. During the transport of drift flints $(1.7 \%$ of the raw materials) from North Bohemia, hunter-gatherers had to overcome more than $260 \mathrm{~km}$. The non determined materials consist of $10 \%$ of the collection.

Site Pernek 3 provided 50 pieces of chipped industry (Table 9). Mesolithic settlers at Pernek 3 occasionally chipped local quartz (8\%). Outcrops in South Bohemia (opal, red silicite) were used at a frequency of $24 \%$ (transport distance $60 \mathrm{~km}$ ) and Bavarian cherts make up $16 \%$ of the assemblage (transport distance $70 \mathrm{~km}$ ). Long-distant imports are represented by the Tušimice type quartzite (transport distance $185 \mathrm{~km} ; 2 \%$ of the production material), the Skršín type quartzite (190 km; $2 \%)$ and drift flints as the furthermost most

Table 8. Pernek 1 and 4. Origin of the stone raw materials (Mesolithic).

\begin{tabular}{|c|c|c|c|c|}
\hline Stone Raw Material & Distance & $\%$ & $\%$ Cumulative & \% Cumulative Modified \\
\hline local sources & 10 & 1.3 & 1.3 & 1.4 \\
\hline sources from South Bohemia & 60 & 10.4 & 11.7 & 13 \\
\hline Bavarian Jurassic chert & 70 & 75.7 & 87.4 & 97.1 \\
\hline sources from the Pilsen basin & 120 & 0.9 & 88.3 & 98.1 \\
\hline area of continental glaciations (drift flints) & 260 & 1.7 & 90 & 100 \\
\hline non determined & $?$ & 10 & & \\
\hline
\end{tabular}

Table 9. Pernek 3. Origin of the stone raw materials (Late Palaeolithic).

\begin{tabular}{|c|c|c|c|c|}
\hline Stone raw material & Distance & $\%$ & $\%$ Cumulative & $\%$ Cumulative modified \\
\hline local sources & 10 & 8 & 8 & 8.7 \\
\hline sources from South Bohemia & 60 & 24 & 32 & 34.8 \\
\hline Bavarian Jurassic chert & 70 & 16 & 48 & 52.2 \\
\hline Tušimice type quartzite & 185 & 2 & 50 & 54.3 \\
\hline Skršín type quartzite & 190 & 2 & 52 & 56.5 \\
\hline area of continental glaciations (drift flints) & 260 & 40 & 92 & 100 \\
\hline non determined & & 8 & & \\
\hline
\end{tabular}


often used stone raw material $(240 \mathrm{~km} ; 40 \%)$. The remainder of the stone raw materials $(8 \%)$ have not been determined.

\subsection{Malé Hydčice 1 (Malé Hydčice village, Klatovy district)}

Archaeological sites under long-term examination conducted by J. Fröhlich, J. Eigner and V. Eigner are located south-west of the village of Malé Hydčice. Hunter-gatherer settlements lie on a significant edge of the left bank of the Otava (Šída et al. 2011). Site number 1 is one of the largest collections in the upper Otava region and consists of 102 artefacts, which have been dated to the Late Palaeolithic with a possible Mesolithic admixture (Table 10). Local stone raw materials represent only $2 \%$ of the industry (transport distance up to $10 \mathrm{~km}$ ), circa $80 \mathrm{~km}$ distant sources from South Bohemia were exploited at a frequency of 3.9\%. Bavarian stropped cherts were transported over a distance of $80 \mathrm{~km}$ and consist of the majority of the production material (74.5\%). Longdistant imports are represented by the Tušimice type of quartzite (transport distance $125 \mathrm{~km} ; 1 \%$ of the production material), Bavarian banded chert so-called Plattensilex (140 km; 8.8\%) and drift flints $(230 \mathrm{~km} ; 9.8 \%)$.

\subsection{Malé Hydčice 2 (Malé Hydčice village, Klatovy district)}

Circa 50 pieces of lithic industry dating back to the Late Palaeolithic were obtained during surface surveys at Malé Hydčice 2 (Table 11). Hunters at Malé Hydčice 2 only occasionally chipped local rocks (4\%). The outcrops in South Bohemia were used at a frequency of $2 \%$ (transport distance $80 \mathrm{~km}$ ). Bavarian cherts, as in the case of the two previous sites, consist of the majority of the assemblage in total $82 \%$ (transport distance $80 \mathrm{~km}$ ). So-called long-distance imports, which means materials transported at a distance over $100 \mathrm{~km}$, are represented by Plattensilex $(140 \mathrm{~km} ; 6 \%)$ and drift flints (more than $230 \mathrm{~km} ; 6 \%$ ).

\subsection{Malé Hydčice 4 (Malé Hydčice village, Klatovy district)}

The assemblage of Late Palaeolithic chipped industry from Malé Hydčice 4 consists of 35 artefacts (Table 12). Over a radius of $10 \mathrm{~km}$, hunter-gatherers obtained $2.9 \%$ of the used stone raw materials. $5.7 \%$ of the chipped rocks and minerals have their origin in the area of South Bohemia. The orientation to Bavaria and "popularity" of the stropped local cherts is also visible in this assemblage. 80 kilometre distant outcrops of stropped cherts in the ortenburgian Jurassic represent a source area of $74.3 \%$ lithic materials, while the more distant $(140 \mathrm{~km})$ Plattensilex from Frankonian Jura consequently represents $17.1 \%$ of the collection.

\subsection{Malé Hydčice 6 (Malé Hydčice village, Klatovy district)}

Table 13 summarises the stone raw materials which were determined in an assemblage of chipped industry from Malé Hydčice 6. In this case local sources of rocks were not used. The nearest outcrops of chipped materials are situated in south Bohemia at a distance of $80 \mathrm{~km}$ ( $6 \%$ of the assemblage) and in Bavaria also at a distance of $80 \mathrm{~km}$. In the case of the Bavarian sources (stropped cherts) the frequency of use is incomparably greater (76\%). Outcrops of Plattensilex and drift flints lie at a distance of 140 respectively $230 \mathrm{~km}$ and cover $15 \%$ and $3 \%$ of the past human needs.

Table 10. Malé Hydčice 1. Origin of the stone raw materials (Late Palaeolithic with a possible Mesolithic admixture).

\begin{tabular}{lccc}
\hline \multicolumn{1}{c}{ Stone raw material } & Distance & \% & \% Cumulative \\
\hline local sources & 10 & 2 & 2 \\
Bavarian stropped chert & 80 & 74.5 & 76.5 \\
sources from South Bohemia & 80 & 3.9 & 80.4 \\
Tušimice type quartzite & 125 & 1 & 81.4 \\
Plattensilex (Bavarian banded chert) & 140 & 8.8 & 90.2 \\
area of continental glaciations (drift flints) & 230 & 9.8 & 100 \\
\hline
\end{tabular}

Table 11. Malé Hydčice 2. Origin of the stone raw materials (Late Palaeolithic).

\begin{tabular}{lccc}
\hline \multicolumn{1}{c}{ Stone raw material } & Distance & \% & \% Cumulative \\
\hline local sources & 10 & 4 & 4 \\
Bavarian stropped chert & 80 & 82 & 86 \\
sources from South Bohemia & 80 & 2 & 88 \\
Plattensilex (Bavarian banded chert) & 140 & 6 & 94 \\
area of continental glaciations (drift flints) & 230 & 6 & 100 \\
\hline
\end{tabular}

Table 12. Malé Hydčice 4. Origin of the stone raw materials (Late Palaeolithic).

\begin{tabular}{lccc}
\hline \multicolumn{1}{c}{ Stone raw material } & Distance & \% & \% Cumulative \\
\hline local sources & 10 & 2.9 & 2.9 \\
Bavarian stropped chert & 80 & 74.3 & 77.2 \\
sources from South Bohemia & 80 & 5.7 & 82.9 \\
Plattensilex (Bavarian banded chert) & 140 & 17.1 & 100 \\
\hline
\end{tabular}


Table 13. Malé Hydčice 6. Origin of the stone raw materials (Late Palaeolithic).

\begin{tabular}{lccc}
\hline \multicolumn{1}{c}{ Stone raw material } & Distance & \% & \% Cumulative \\
\hline Bavarian stropped chert & 80 & 76 & 76 \\
sources from South Bohemia & 80 & 6 & 82 \\
Plattensilex (Bavarian banded chert) & 140 & 15 & 97 \\
area of continental glaciations (drift flints) & 230 & 3 & 100 \\
\hline
\end{tabular}

Table 14. Týnec 3. Origin of the stone raw materials (Mesolithic).

\begin{tabular}{lccc}
\hline \multicolumn{1}{c}{ Stone raw material } & Distance & $\mathbf{\%}$ & \% Cumulative \\
\hline Bavarian stropped chert & 80 & 94 & 94 \\
sources from South Bohemia & 80 & 3 & 97 \\
sources from the Pilsen basin & 80 & 3 & 100 \\
\hline
\end{tabular}

Table 15. Žichovice 6. Origin of the stone raw materials (Magdalenian, Late Palaeolithic).

\begin{tabular}{lccc}
\hline \multicolumn{1}{c}{ Stone raw material } & Distance & \% & \% Cumulative \\
\hline Bavarian stropped chert & 80 & 84.6 & 84.6 \\
sources from South Bohemia & 80 & 3.3 & 87.9 \\
Krumlovský les type chert & 200 & 1.1 & 89 \\
area of continental glaciations (drift flints) & 230 & 11 & 100 \\
\hline
\end{tabular}

\subsection{Týnec 3 (Týnec village, Klatovy district)}

This site is localized on a Týnec cadastral territory on a field at a position "Na Stráních". The area of the site has a south and southeast slope and lies on the left bank of the Otava at an elevation of $10 \mathrm{~m}$. The assemblage of 36 Mesolithic artefacts was collected by J. Fröhlich, J. Michálek, J. Eigner and V. Eigner (Table 14). The studied chipped industry was almost exclusively made up of Bavarian stropped cherts $(94 \% ; 80 \mathrm{~km})$, the same distance of South Bohemia sources and outcrops of the Pilsen basin (both $80 \mathrm{~km})$ covered just $6 \%$ of the production material (3\% each). Local and long-distance materials were not used.

\subsection{2 Žichovice 6 (Žichovice village, Klatovy ditrict)}

The archaeological site at Žichovice 6 is on significant hillock outgoing from Kuneš hill $(506 \mathrm{~m})$ above the right bank of the Otava at a distance of $110 \mathrm{~km}$ from the river (elevation $36 \mathrm{~m}$ ). Repeated surface collections conducted by J. Eigner and V. Eigner in 2004-2007 provided 91 pieces of the lithic industry. The majority of them date back to the Late Palaeolithic, although certain artefacts have features of Upper Palaeolithic Magdalenian culture (Table 15). Circa $80 \mathrm{~km}$ distant sources from South Bohemia were exploited at a frequency of $3.3 \%$. Bavarian stropped cherts were also transported at a distance of $80 \mathrm{~km}$ and make up the majority of the production material $(84.6 \%)$. Long-distant imports are represented by the Krumlovský les type chert (transport distance $200 \mathrm{~km} ; 1.1 \%$ of the production material) and drift flints (more than $230 \mathrm{~km} ; 11 \%$ ).

\section{Use of the stone raw materials}

The structures, which represent regularities in the use of rocks and minerals, were determined based on a determination of the stone raw material composition of the chipped industry. These regularities, so-called exploitation models, are dependent on the chronological determination of the artefacts and also on the spatial localisation of the archaeological sites. For the Late Palaeolithic and Mesolithic period there is a separate model, which is modified in different regions of Bohemia, in this case in the Protected Landscape Area of the Bohemian Paradise, the area around the upper Otava river and the Central Bohemian region. The stone raw material analyses made possible a derivation of the transport distance of the chipped stone artefacts production materials and subsequently the establishment of an action radius of huntergatherer movement and a picture of the settlement at a certain moment of the Late Palaeolithic and Mesolithic. The abovementioned exploitation models reflected human behaviour in relation to stone raw materials and offer a certain possibility of chronological determination of part or even of entire assemblages which are not dated with certainty or are dated in a longer interval (e.g. Late Palaeolithic-Mesolithic).

A specific trend (Table 16, Figure 1,2) appears at all of the studied sites in the Bohemian Paradise. As in the Late Palaeolithic (Daliměřice) as well in the Mesolithic (Babí pec revision research in 2003 and 2006, Kristova jeskyně, Hlavatá skála research in 2010) the main part of the stone raw materials (98-100\%) was obtained from the outcrops, which are situated up to $40 \mathrm{~km}$ from the archaeological site. The remainder of the chipped industry was made from high-quality quartzites of the Skršín, Bečov and Tušimice type brought from northwest Bohemia, distance of $110 \mathrm{~km}$, and in the case of the last one $140 \mathrm{~km}$. A Bavarian banded chert was additionally determined in the Mesolithic collection from Babí pec. The outcrops lie in the Frankish Albums at a distance of $350 \mathrm{~km}$ (Figure 3). This means that the everyday needs of the stones were covered by movement within $40 \mathrm{~km}$ of the camps. The 
Table 16. Studied sites. The relationship between the quantity of the raw material and the transport distance.

\begin{tabular}{|c|c|c|c|c|c|c|c|c|c|c|c|c|c|}
\hline \multirow{2}{*}{ Site } & \multicolumn{12}{|c|}{ Quantity of raw material (\%)/distance (km) } & \multirow{2}{*}{ Dating } \\
\hline & 10 & 20 & 30 & 40 & 50 & 60 & 70 & 80 & 90 & 95 & 99 & 100 & \\
\hline babí pec, revision & 1 & 1 & 1 & 1 & 8 & 40 & 40 & 40 & 40 & 40 & 40 & 40 & Mesolithic \\
\hline Kristova jeskyně & 4 & 5 & 35 & 35 & 35 & 35 & 35 & 35 & 35 & 35 & 35 & 134 & Mesolithic \\
\hline Hlavatá skála, 2010 & 5 & 5 & 5 & 5 & 5 & 9 & 12 & 12 & 43 & 43 & 43 & 43 & Mesolithic \\
\hline Pernek 1,4 & 60 & 70 & 70 & 70 & 70 & 70 & 70 & 70 & 70 & 70 & 260 & 260 & Mesolithic \\
\hline Týnec 3 & 80 & 80 & 80 & 80 & 80 & 80 & 80 & 80 & 80 & 80 & 80 & 80 & Mesolithic \\
\hline Babí pec 1936 & 1 & 1 & 1 & 1 & 5 & 8 & 10 & 40 & 40 & 40 & 40 & 350 & Mesolithic, Late Palaeolithic? \\
\hline Malé Hydčice 1 & 80 & 80 & 80 & 80 & 80 & 80 & 80 & 80 & 140 & 230 & 230 & 230 & Late Palaeolithic, Mesolithic? \\
\hline Daliměřice & 9 & 35 & 35 & 35 & 35 & 35 & 35 & 35 & 35 & 35 & 35 & 100 & Late Palaeolithic \\
\hline Pernek 3 & 60 & 60 & 60 & 70 & 70 & 260 & 260 & 260 & 260 & 260 & 260 & 260 & Late Palaeolithic \\
\hline Malé Hydčice 2 & 80 & 80 & 80 & 80 & 80 & 80 & 80 & 80 & 140 & 230 & 230 & 230 & Late Palaeolithic \\
\hline Malé Hydčice 4 & 80 & 80 & 80 & 80 & 80 & 80 & 80 & 80 & 140 & 140 & 140 & 140 & Late Palaeolithic \\
\hline Malé Hydčice 6 & 80 & 80 & 80 & 80 & 80 & 80 & 80 & 80 & 140 & 140 & 230 & 230 & Late Palaeolithic \\
\hline Žichovice 6 & 80 & 80 & 80 & 80 & 80 & 80 & 80 & 80 & 230 & 230 & 230 & 230 & Magdalenian, Late Palaeolithic \\
\hline Hlavatá skála, 1905 & 8 & 9 & 12 & 12 & 43 & 43 & 43 & 43 & 43 & 43 & 130 & 130 & Mesolithic, Late Palaeolithic \\
\hline Kozly & 10 & 50 & 60 & 60 & 60 & 60 & 60 & 70 & 90 & 90 & 100 & 200 & Mesolithic, Late Palaeolithic \\
\hline
\end{tabular}

use of raw materials from more distant outcrops is sporadic, and always only involved rare pieces of quartzites or cherts from a distance of over $100 \mathrm{~km}$. Their presence reflects other aspects of hunter-gatherer behaviour, for example, perhaps representing evidence of long-distance trips on the part of the community, a connection with a previous settlement area or documenting inter-community contact.

The basic framework for the movement of groups of Late Palaeolithic and Mesolithic hunter-gatherers in the Bohemian Paradise is the same, although clear differences are reflected by the frequency of the use of the individual rocks and minerals in particular. It is possible that the assumed base for the studied sample, for the Late Palaeolithic period, is characterised by the use of drift flints from North Bohemia at the expense of minerals from Kozákov Hill and of other local sources available up to $10 \mathrm{~km}$. In contrast, in the following Mesolithic period there is an evident inclination to the above-mentioned minerals and local rocks from fluvial sediments of the Jizera River or from local Permian sediments. The percentage of long-distance imports from north-west Bohemia is only in tenths of a per cent in both the studied periods. The area of the Bohemian Paradise is a
Figure 3. Bohemian Paradise, Late Palaeolithic and Mesolithic sites. Transport of the stone raw materials.

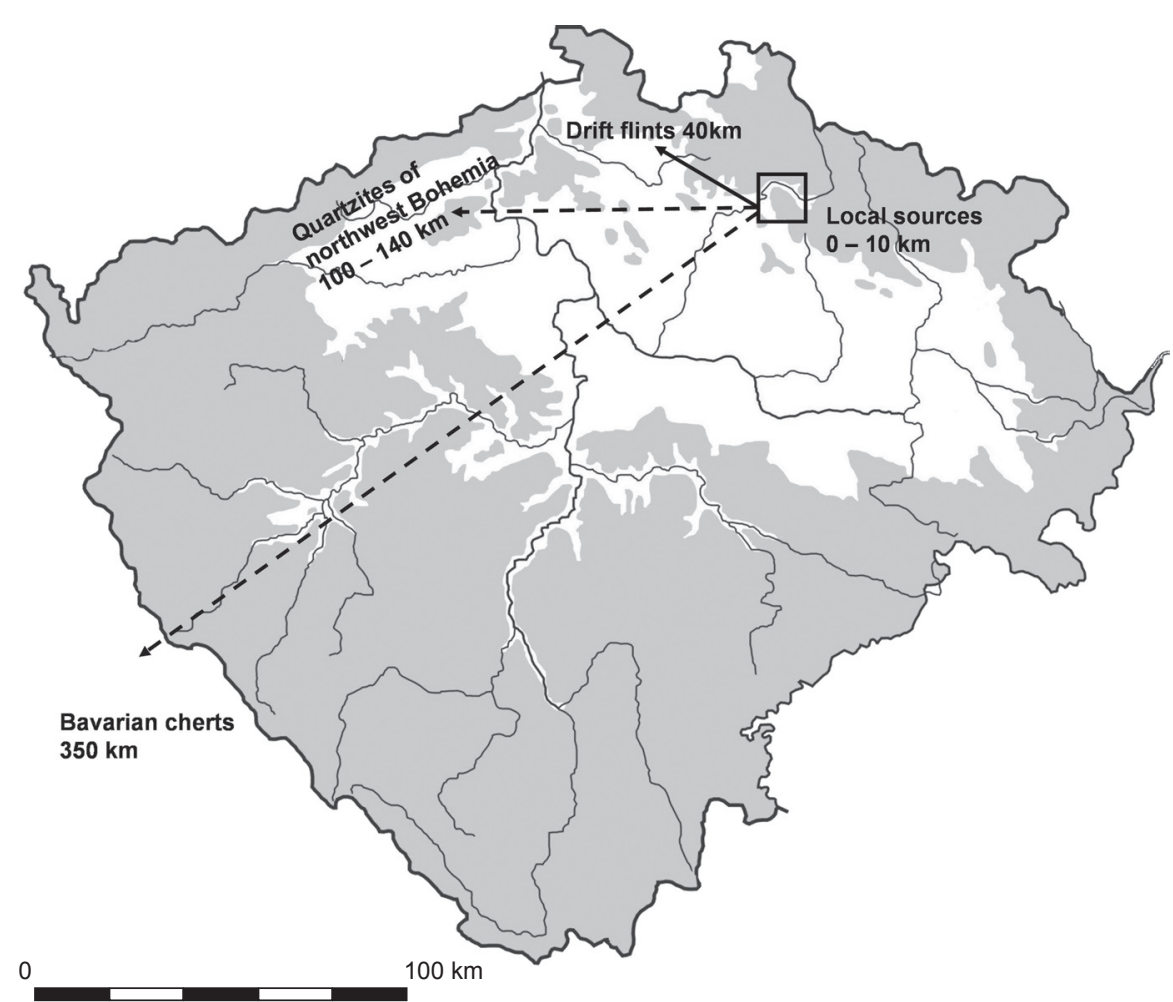




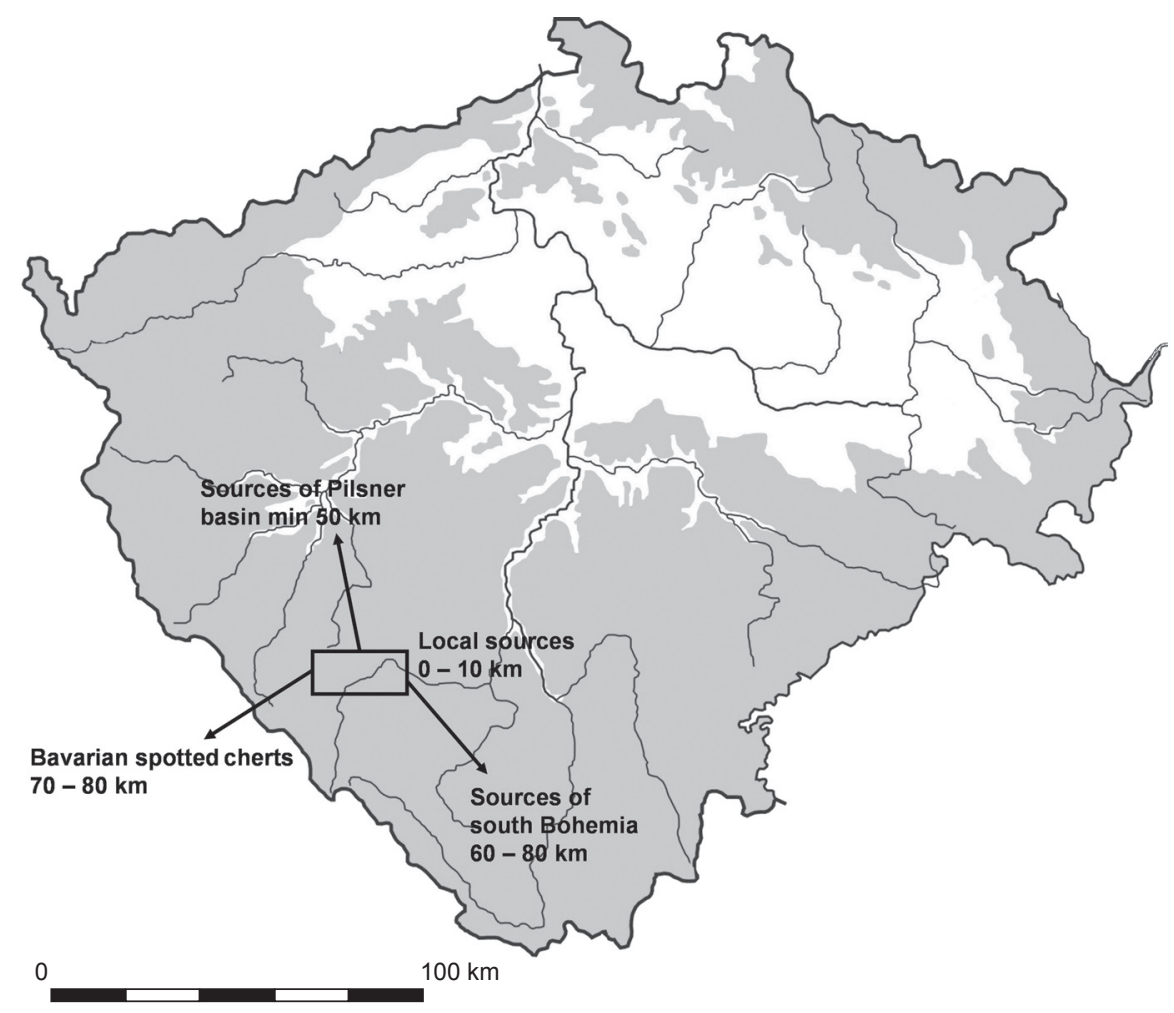

Figure 4. Upper Otava region, Mesolithic sites. Transport of the stone raw materials.

typical example of an area with occurrences of high-quality stone raw materials with this fact undoubtedly affecting the exploitation strategy.

The area of the upper Otava River is another region where mobility of Late Palaeolithic and Mesolithic hunter-gatherer groups was studied based on analyses of their stone artefact raw materials (for the spatial definition of the upper Otava see Š́da et al. 2011). Three groups of stone raw materials were defined in the chipped industry assemblages based on their transport distance: local rocks and minerals available up to $10 \mathrm{~km}$, production materials from outcrops distant 60-80 km (sources from South Bohemia, spotted varieties of Bavarian Jurassic cherts) and stones transported over a distance, which markedly exceeded the $100 \mathrm{~km}$ boundary (quartzites of north-west Bohemia, banded chert from Bavaria so-called Plattensilex, drift flints from North Bohemia).

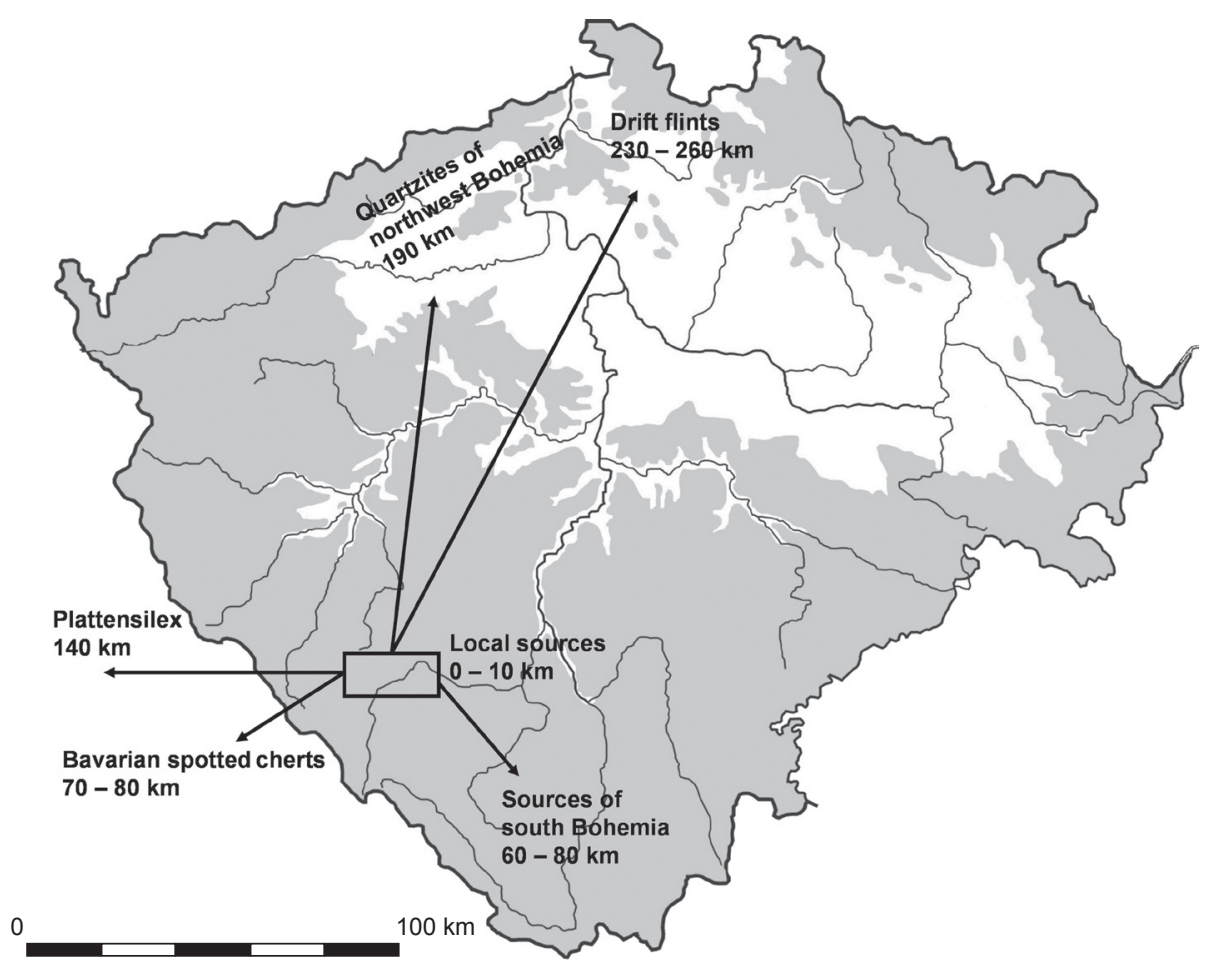

Figure 5. Upper Otava region, Late Palaeolithic sites. Transport of the stone raw materials. 
Figure 6. Central Bohemia region, Late Palaeolithic sites. Transport of the stone raw materials.

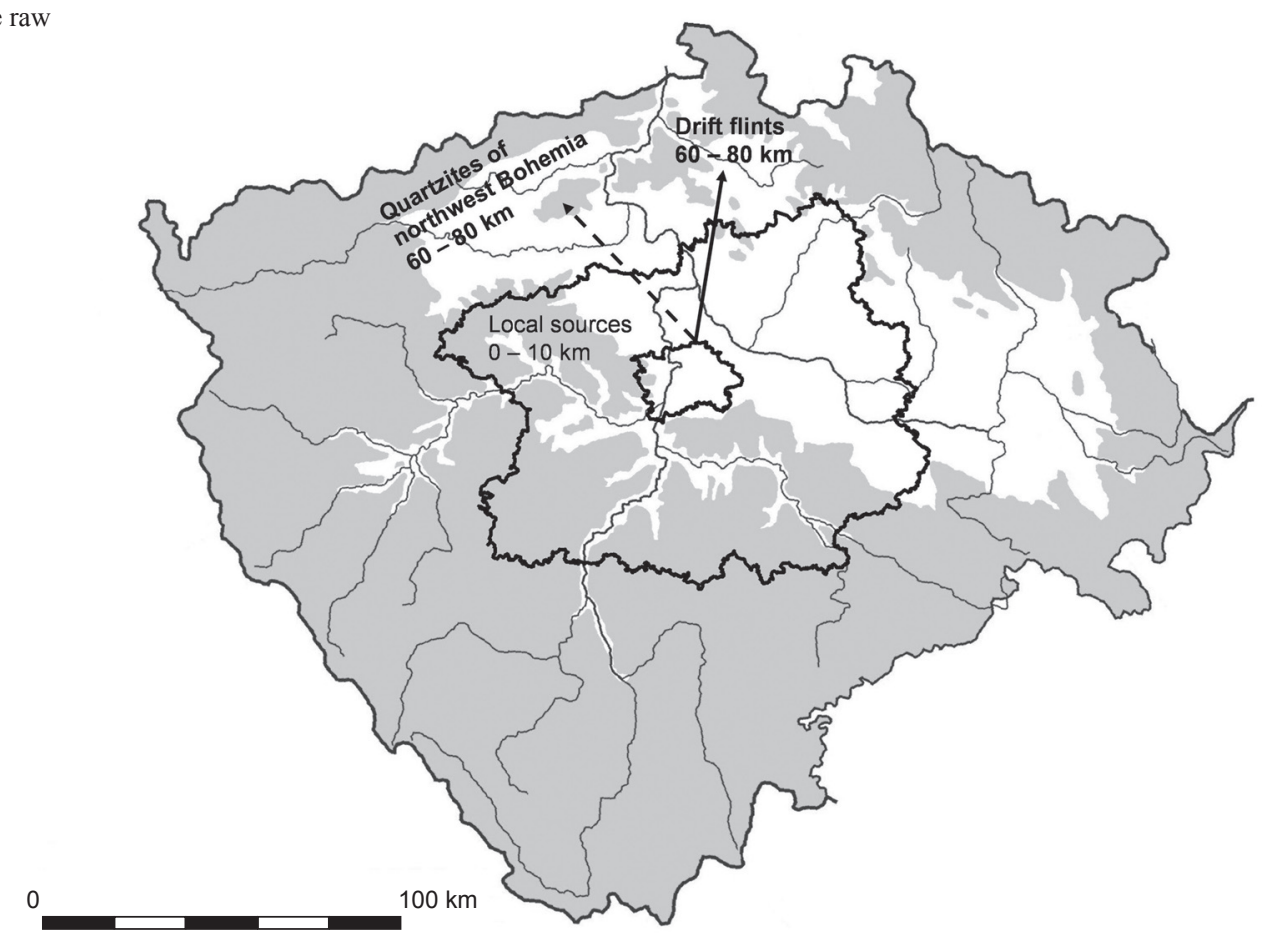

The late Palaeolithic industry is from the point of view of stone raw material exploitation characterised, in contrast with the Mesolithic industry, by the use of banded cherts from the vicinity of Regensburg (so-called Plattensilex), which rank among the group of long-distance imports (transport distance $140 \mathrm{~km}$ ). The spotted varieties of Bavarian Jurassic cherts from the ortenburgian Jurassic (transport distance about $80 \mathrm{~km}$ ) are at certain Late Palaeolithic sites a dominant part of the production stone materials, while at the rest of the sites there is a prevalence of drift flints brought from a distance of 230-260 km. The exploitation of drift flints is the next specific feature of the Late Palaeolithic period at the upper Otava region as well as the rare use of the Tušimice and Skršín type quartzite with circa 190 km distant outcrops

Figure 7. Central Bohemia region, Mesolithic sites. Transport of the stone raw materials.

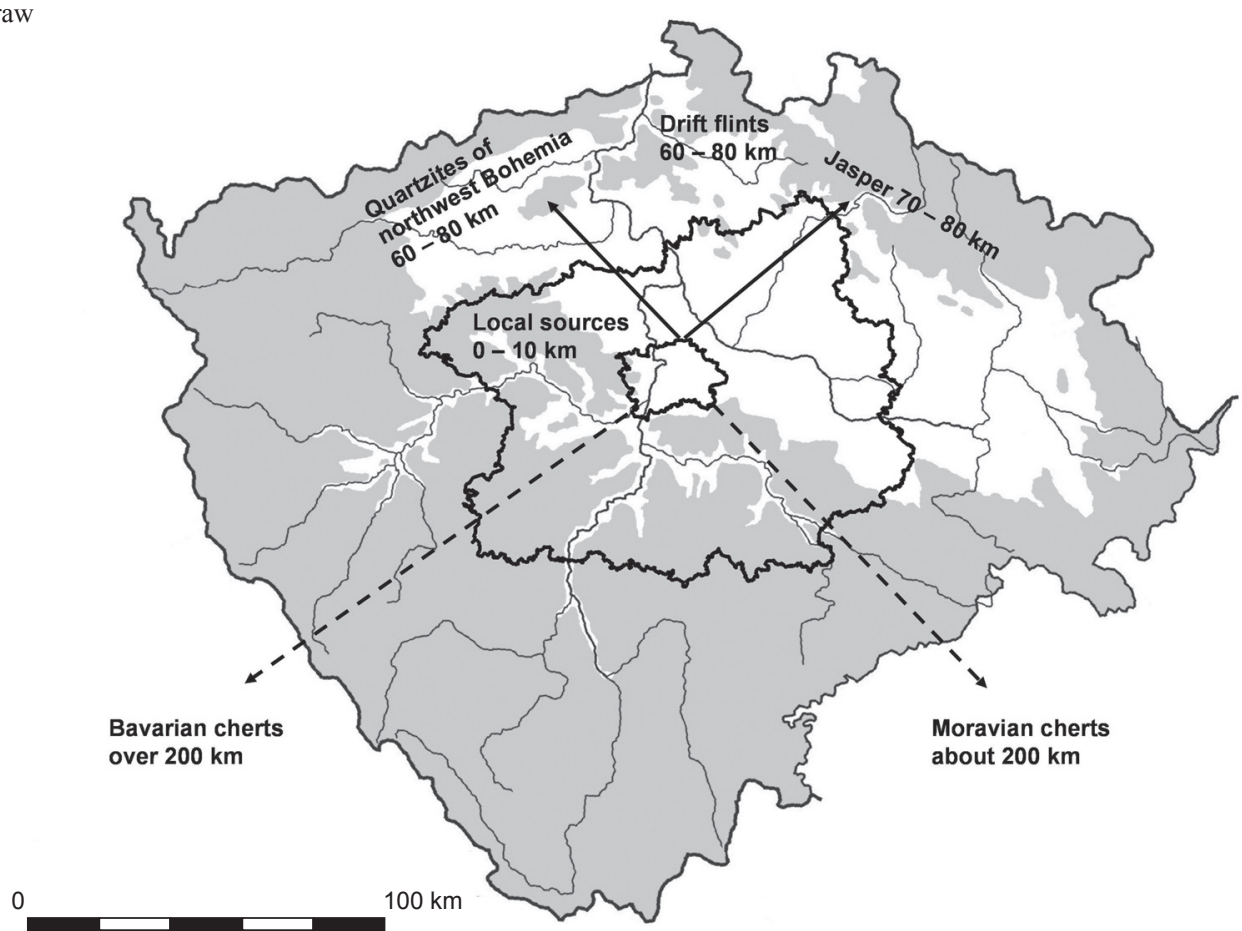


(see Malkovský, Vencl 1995). Occasional chipping of local rocks and of stone raw materials from South Bohemia is a common practice in the Late Palaeolithic as well as in the Mesolithic. Exploitation strategy during the Mesolithic is based on stropped Bavarian cherts which as this time made up about $80 \%$ of the stone raw materials of the individual chipped industry assemblages. Remarkable at first sight is the absence of banded cherts from Bavaria and also of drift flints from North Bohemian spurts and basins. These silicites were replaced by the above-mentioned stropped cherts. A certain change in contrast to the Late Palaeolithic consists of the occasional use of rocks from the Pilsen basin located a minimum of $50 \mathrm{~km}$ north-west from the archaeological sites at the upper Otava region.

Mesolithic hunters and gatherers who settled in the upper Otava region primarily focused their attention on Bavarian sources which were located circa $80 \mathrm{~km}$ south-westerly. Part of this consisted of chipped industry made from raw materials from South and West Bohemia, which were potentially also available up to $80 \mathrm{~km}$. Long-distance imports from Bavaria or north-west and northern parts of Bohemia are missing. The Mesolithic community movement, or in other words a derived exploitation model, is documented on an attached map (Figure 4). The action radius of the Late Palaeolithic groups extends from North Bohemia (use of drift flints) and outcrops of quartzites in north-west Bohemia, over to the South Bohemia region up to the Bavarian territory to the sources of the banded cherts in the Frankish Albums and the stropped cherts in the ortenburgian Jurassic (Figure 5). These rocks and minerals were brought to the upper reaches of the Otava River by humans at the time in the form of raw material, semi-finished products or finished artefacts. This behaviour is partly related to the lack of suitable local sources.

Flints from glacial and glaciofluvial sediments were determined in all of the seven studied assemblages of the Late Palaeolithic in Central Bohemia (Central Bohemia region, mostly the northern part). Flints were used exclusively at four sites, while the main part of the production materials is represented at the rest of the sites. At Mladá Boleslav there was in addition chipped agate and marlite, at the PragueMalešice quartzites of the Bečov, Skršín and Tušimice type and also quartz, and porcellanites at the Kvíc site (Prostředník, Šída 2003, 183; Vencl, Motyl 1998, 838; Benková 2003, 38-39). Due to the wide range of the Central Bohemia region and the large variability in the spatial location of the archaeological sites there is also a large variability in the transport distance of the drift flints, the average values (arithmetic mean, median) are $60-80 \mathrm{~km}$. The area used to obtain rocks for production of stone artefacts by Late Palaeolithic hunter-gatherer groups involved the northern part of Bohemia, primarily the border area, which was affected by continental glaciation (Figure 6).

Quartzite from north-west Bohemia (Bečov type, Skršín type, Tušimice type) and jasper were transported at a large number of Mesolithic sites (from 1/4 to 1/3) in the Central Bohemia region. The dominance of drift flints is not as visible as this time. This material was determined in half of the studied Mesolithic sites (24 sites from 47). A frequency of use in the individual chipped industry assemblages is primarily between $30 \%$ and $40 \%$. In contrast to the previous Late Palaeolithic period, there is a growing importance of quartzes and phthanites and also the chert of the Bohemian Karst type. All the above-mentioned rocks date back to the Proterozoic and Paleozoic siliceous rocks from the area of Barrandien in the Central Bohemia region and represent local stone raw materials. In summary, Mesolithic chipped industry assemblages in Central Bohemia are characterised by a large diversity of production materials and a larger spatial variability of the hunter-gatherer movement than in the Late Palaeolithic. Stone raw materials originating in Moravia and Bavaria appear at certain archaeological sites. The exploitation model reflects a combination of rocks and minerals from the category of long-distance imports and from the category of local sources available up to $10 \mathrm{~km}$. The action radius extends outside the Central Bohemia region primarily to the north-west and north-east direction, the average transport distance of the Bečov and Skršín type quartzite is $60 \mathrm{~km}$, the Tušimice type quartzite and jasper 80 km (Moravcová 2010; Figure 7).

The chipped industry without typological (chronological) sensitive features was assessed separately. This amounts to assemblages dating back to the interval Late Palaeolithic - Mesolithic, namely sites in the Bohemian Paradise, Babí pec (research in 1936) and Hlavatá skála (research at the beginning of the $20^{\text {th }}$ century) and the site at Malé Hydčice 1 in the area of the upper Otava River. A Mesolithic collection with a possible admixture of the Late Palaeolithic industry is represented by a site at Kozly (Mělník district). In the case of Žichovice 6 (Klatovy district, upper Otava River) they are assemblages with features characteristic for the Upper Palaeolithic Magdalenian and the industry of the Late Palaeolithic.

The above described exploitation models can help with the chronological classification of the above-mentioned assemblages or of their greater part. The significant frequency of the use of drift flints (56.8\%), at the expense of minerals, originated from Kozákov Hill and its surroundings, together with the chipping of the Skršín and Tušimice type quartzites designated from the chipped industry from Hlavatá skála (research at the beginning of the $20^{\text {th }}$ century) with a preference for the end of the Palaeolithic rather than for the Mesolithic. Additionally, the stone raw material composition of the chipped industry from Malé Hydčice 1 is more consistent with the exploitation model derived from the Late Palaeolithic industries of the upper Otava region: the chipping of the Plattensilex (8.8\%), drift flints (9.8\%) and the Tušimice type of quartzite (1\%). An assemblage obtained in 1936 at Babí pec seems to be completely mixed as there is a practically balanced proportion between drift flints (41.9\%) and minerals from Kozákov Hill (40.7\%) and because the differentiation between the frequency of use of the flints and the above-mentioned minerals are, from the point of view of the stone raw materials exploitation, the main determining 
feature of the Late Palaeolithic and Mesolithic assemblages in the Bohemian Paradise. The site Kozly (Mělník district) fits into the framework of the Mesolithic exploitation strategy in the Central Bohemia region. It is a structure that captures the conjoint occurrence of certain stone raw materials, which are at individual sites chipped with extremely similar use of frequency (quartzites from north-west Bohemia, jaspers from Kozákov hill and cherts of the Bohemian Karst type).

\section{Conclusions}

The article presents a possible approach to the study of mobility or in other words to the determination of movement radius of hunter-gatherer groups (communities). The proclaimed approach is based on an analysis of raw materials which were used by primeval producers for production of their stone artefacts. Late Palaeolithic and Mesolithic industry assemblages from three regions were selected for this purpose, with these being located in different parts of Bohemia: the area of the Bohemian Paradise, the upper Otava region and the Central Bohemia region. The structures were inferred, the so-called exploitation models, on the basis of a determination of the used rocks and minerals along with a derivation of their transport distance. These models are chronological and spatial sensitive, which means that different models, which are moreover modified within the individual studied regions, are characteristic for the Late Palaeolithic and Mesolithic period.

The study of exploitation models (structures in the use of stone raw materials) is an important tool for understanding the movement of hunter-gatherer communities over a particular time and area.

\section{Acknowledgements}

The emergence of this article was supported by the project OP VK Partnership for Archaeology (CZ.1.07/2.4.00/17.0056) and the project $\mathrm{OP} \mathrm{VK}$ Archaeological strategies (CZ.1.07/2.3.00/20.0036), which are financed by the European Social Fund and the state budget of the Czech Republic.

\section{References}

BENKOVÁ, I. 2003: Epimagdalénská stanice v Kvíci u Slaného, Archeologie ve středních Čechách 7/1, 33-72.

FILIP, J. 1947: Dějinné počátky Českého ráje. Prague.

MALKOVSKÝ, M., VENCL, S. 1995: Quartzites of north-west Bohemia as Stone Age raw materials. Environs of the towns of Most and Kadaň, Czech Republic, Památky archeologické 86, 5-37.

MORAVCOVÁ, M. 2010: Exploatace surovin kamenné štípané industrie v paleolitu a mezolitu středních Čech. Master's thesis. Deposited: Library of the Faculty of Philosophy and Arts, University of West Bohemia, Plzeň.

PETRBOK, J. 1937: Stratigrafie mikrolitické stanice u Kozel nad Labem, Obzor praehistorický 10, 280-283.

PROSTŘEDNÍK, J., ŠIIDA, P. 2003: Mladá Boleslav čp. 101: Stratigrafie sondy 21/93, Archeologie ve středních Čechách 7/1, 175-198.

PROSTŘEDNÍK, J., ŠÍDA, P. 2006: Mezolitické osídlení pseudokrasových skalních dutin v Českém ráji. In: Sbornik z konference 50. let CHKO Český Ráj, Z Českého ráje a Podkrkonoši - supplementum 11, 83-106.

PROSTŘEDNÍK, J., ŠÍDA, P. 2010: Nejstarši dějiny Českého ráje a horního Pojizeři. Muzeum Českého ráje v Turnově, Turnov.

SKLENÁŘ, K. 1982: Pravěké nálezy na Mélnicku a Kralupsku. Archeologický místopis okresu Mělník v pravěku a rané době dějinné. Borek-Mělnické Vtelno. Mělník.

SKLENÁ̌̌, K. 2000: Hořin III. Mesolithische und hallstattzeitliche Siedlung. Fontes Archaeologici Pragenses 24. Prague.

SKLENÁŘ, K. 2008: Dějiny výzkumu starší a střední doby kamenné (paleolitu a mezolitu) v Českých zemích, Sborník Národního muzea v Praze, r̆ada A-Historie 62/2-4.

SVOBODA, J. A. (Ed.) 2003: Mezolit severních Čech. Komplexní výzkum skalních převisů na Českolipsku a Děčinsku 1978-2003. Dolnověstonické studie 9. Archeologický ústav AV ČR Brno, Brno.

ŠÍDA, P. 2004: Pozdně paleolitická industrie z hradiště u Dolánek, k. ú. Daliměřice (okr. Semily), Archeologie ve středních Čechách 8, 77-102.

ŠÍDA, P. 2007: Využivání kamenné suroviny v mladši a pozdní době kamenné, Dílenské areály v oblasti horniho Pojizeři. Dissertationes archaeologicae Brunenses/Pragensesque 3, Masarykova univerzita, Karlova univerzita, Praha - Brno.

ŠÍDA, P., EIGNER, J., FRÖHLICH, J., MORAVCOVÁ, M., FRANZEOVÁ, D. 2011: Doba kamenná v povodi Horni Otavy. Archeologické výzkumy v jižních Čechách, Supplementum 7, České Budějovice - Plzeň.

ŠÍDA, P., FRÖHLICH, J., CHVOJKA, O. 2008: Pozdně paleolitická a mezolitická stanoviště na horní Vltavě u Perneku. Nové poznatky o předneolitickém osídlení Lipenska, Archeologické výzkumy v jižních Čechách 21, 3-29.

ŠÍDA, P., PROSTŘEDNÍK, J. 2006: Mezolit pod Hlavatou skálou v Českém ráji (k. ú. Hrubá Skála, okr. Semily). In: Vencl, S, Sigl, J., Sedláček, R. (Eds.): Vita Archaeologica. Hradec Králové - Pardubice, 207-228.

ŠÍDA, P., PROSTŘEDNÍK, J. 2007: Mezolit a pozdní paleolit Českého ráje: perspektivy poznání region, Archeologické rozhledy 59/3, 443-460.

ŠÍDA, P., PROSTŘEDNÍK, J. 2010: Předneolitické osídlení pseudokrasu Českého ráje. In: Krištuf, P., Vařeka, P. (Eds.): Opomíjená archeologie 2007-2008. Plzeň, 112-129.

ŠKRDLA, P. 2005: The Upper Paleolithic on the Middle Course of the Morava River. Dolnověstonické studie 13. Archeologický ústav AV ČR Brno, Brno.

VENCL, S. (Ed.) 2006: Nejstarši osidlení jižních Čech. Paleolit a mesolit. Archeologický ústav AV ČR Praha, Praha.

VENCL, S., MOTYL, J. 1998: Pozdně paleolitická industrie z Prahy 10 -Malešic, Archeologické rozhledy 50/4, 837-842, 901.

VOKOLEK, V. 1998: Eneolitické nálezy u „Hlavaté skály“, k.ú. Hrubá skála. In: Prostředník, J., Vokolek, V. (Eds): Otázky neolitu a eneolitu našich zemí. Turnov - Hradec Králové, 113-122. 
